\title{
KEPUASAN KERJA DAN DAMPAKNYA TERHADAP PROFESIONALISME GURU
}

\author{
Fiska Ilyasir \\ (Dosen PAI Sekolah Tinggi Ilmu Agama Alma Ata Yogyakarta)
}

\begin{abstract}
Abstrak
This article attempts to discuss the impact of job satisfaction of teachers in Indonesia to their performance as professional educators. There are several factors that affect their satisfaction of the teacher. Psychological factor, which is related to mental and attitudes, including interest, talent, and skills; Social factor, that related to their social interaction with superiors, colleagues, students, and community. Physical factors, the factor related to the condition of the school such as policies that applied, type of work, working time, school facilities, teaching equipment facilities, teacher's office. teacher physical conditions like health, age, and so on. Financial factors that associated with security and welfare, including sallary, social security, work promotion, and so on. All of these factors certainly can not be changed only by the teacher, but they also need belp from external parties, both government and society.
\end{abstract}

\section{Keyword: Professional Educators}

\section{A. Pendahuluan}

Lembaga pendidikan yang siap berkompetisi harus memiliki manajemen yang efektif. Untuk meningkatkan kinerja personalia, baik guru maupun karyawan lainnya, dalam manajemen yang efektif memerlukan dukungan personaliapersonalia yang cakap dan kompeten di bidangnya. Di sisi lain pembinaan para guru dan karyawan termasuk yang harus diutamakan sebagai usaha pengembangan lembaga pendidikan. Proses belajar harus menjadi budaya sehingga keterampilan dan profesionalitas para tenaga pendidikan dapat dipelihara, bahkan dapat ditingkatkan.

Personalia pendidikan, dalam hal ini guru, dosen, dan staf lainnya, yang memiliki sikap perjuangan, pengabdian, disiplin, dan kemampuan profesional sangat mungkin mempunyai prestasi kerja dalam melaksanakan tugas sehingga lebih berdaya guna dan berhasil guna. Personalia pendidikan yang profesional dapat diartikan sebagai sebuah pandangan untuk selalu berpikir, kerja keras, bekerja sepenuh waktu, disiplin, jujur, loyalitas tinggi, dan penuh dedikasi demi untuk keberhasilan pekerjaannya 
dalam melakukan proses pendidikan. ${ }^{1}$

Di sisi lain, salah satu sasaran penting dalam manajemen sumberdaya manusia pada suatu organisasi, termasuk lembaga pendidikan, adalah terciptanya kepuasan kerja anggota organisasi yang bersangkutan. Kepuasan kerja tersebut diharapkan pencapaian visi dan misi organisasi akan lebih baik dan akurat. Hasil penelitian Herzberg menyatakan bahwa faktor yang mendatangkan kepuasan adalah prestasi, pengakuan, pekerjaan itu sendiri, tanggung jawab, dan kemajuan. ${ }^{2}$ Pendapat lainnya menyatakan bahwa kepuasan kerja adalah keadaan emosional yang menyenangkan atau tidak menyenangkan dengan mana para karyawan memandang pekerjaan mereka. ${ }^{3}$

Pengertian di atas, menggambarkan bahwa penyempurnaan di bidang personalia pendidikan, termasuk guru, hanya selalu mendapat perhatian untuk menuju personalia profesional dengan berbagai pendekatan dan kebijaksanaan. Untuk itu, diperlukan adanya pembinaan, penyadaran, dan kemauan kerja yang tinggi untuk mencapai kinerja yang diharapkan.

Maka dari itu, dalam karya ilmiah yang ada di tangan pembaca ini, penyusun akan mencoba bagaimana posisi kepuasan kerja personalia menurut teori-teori yang terkait. Kemudian pembahasan akan difokuskan pada kepuasan kerja guru bangsa. Berikut ini pembahasannya.

\section{B. Beberapa Teori Kepuasan Kerja}

Teori kepuasan kerja menurut Wesley dan Yulk dapat diterangkan menurut tiga macam teori, yaitu: Pertama, Teori Pertentangan (discrepancy theory) mengemukakan bahwa untuk mengukur kepuasan kerja seseorang dengan menghitung selisih antara apa yang seharusnya dengan kenyataan yang dirasakan. Kemudian, Locke menerangkan bahwa kepuasan kerja tergantung pada ketidaksesuaian antara harapan, kebutuhan, atau nilai yang didapat (expectation, needs atau values) dengan apa yang menurut perasaannya atau persepsinya telah diperoleh atau dicapai melalui pekerjaan. Dengan demikian, orang akan merasa puas bila tidak ada perbedaan antara yang

${ }^{1}$ Hamid, E.S (2003), Membangun Profesional Muhammadiyah, Yogyakarta: LPTP Muhammadiyah dan UAD PRESS, hlm. 40

${ }^{2}$ Armstrong, M. (1994), Manajemen Sumber Daya Manusia, Jakarta: Media Kompetindo, hlm. 71

${ }^{3}$ Handoko, T. Hani (2001), Manajemen Personalia dan Sumber Daya Manusia, Yogyakarta: BPFE, hlm. 193 
diinginkan dengan persepsinya atas kenyataan karena batas minimum yang diinginkan telah terpenuhi.

Kedua, Teori Keadilan (equity theory) yang dikembangkan oleh Adam (1963). Pada prinsipnya teori ini mengemukakan bahwa orang akan merasa puas sepanjang mereka merasa ada keadilan. Perasaan adil dan tidak adil atas suatu situasi diperoleh orang dengan cara membandingkan dirinya dengan orang lain yang sekelas, sekantor, maupun di tempat lain. Teori ini mengidentifikasi elemenelemen keadilan meliputi tiga hal, yaitu: (a) input, adalah sesuatu yang berharga yang dirasakan oleh pegawai sebagai masukan terhadap pekerjaannya; (b) out comes, adalah segala sesuatu yang berharga yang dirasakan sebagai dari hasil pekerjaannya; (c) comparisons persona, adalah perbandingan antara input dan out comes yang diperolehnya.

Ketiga, Teori dua faktor (Two factor theory) yang dikemukakan oleh Herzberg (1966). Prinsip-prinsip teori ini adalah bahwa kepuasan dan ketidakpuasan terhadap pekerjaan itu tidak merupakan variabel yang berkesinambungan. ${ }^{4}$ Berdasarkan hasil penelitiannya Herzberg membagi situasi yang mempengaruhi sikap seseorang terhadap pekerjaannya menjadi dua kelompok yaitu: (a) kelompok puas (satisfiers) atau motivator, faktorfaktor atau situasi yang dibuktikan sebagai sumber kepuasan yang terdiri dari: penghargaan (achievement), pengakuan (recognition), unsur kerja itu sendiri (work it self), tanggungjawab (responsibility) dan kemajuan (advancement); dan (b) kelompok tidak puas (dissatisfiers) atau bygiene factors, yaitu faktor-faktor yang terbukti menjadi sumber ketidakpuasan, seperti: kebijakan dan administrasi kerja (company policy and administration), teknik supervisi (supervision technical), upah/gaji (salary), hubungan antar pribadi (interpersonal relations), kondisi kerja (working condition), keamanan kerja (job security) dan status. Untuk lebih jelasnya kita dapat melihat diagram teori dua faktor di bawah ini:

${ }^{4}$ As'ad, M (2003), Psikologi Industri; Seri Sumber Daya Manusia, Yogjakarta: Liberty, hlm. 108. 


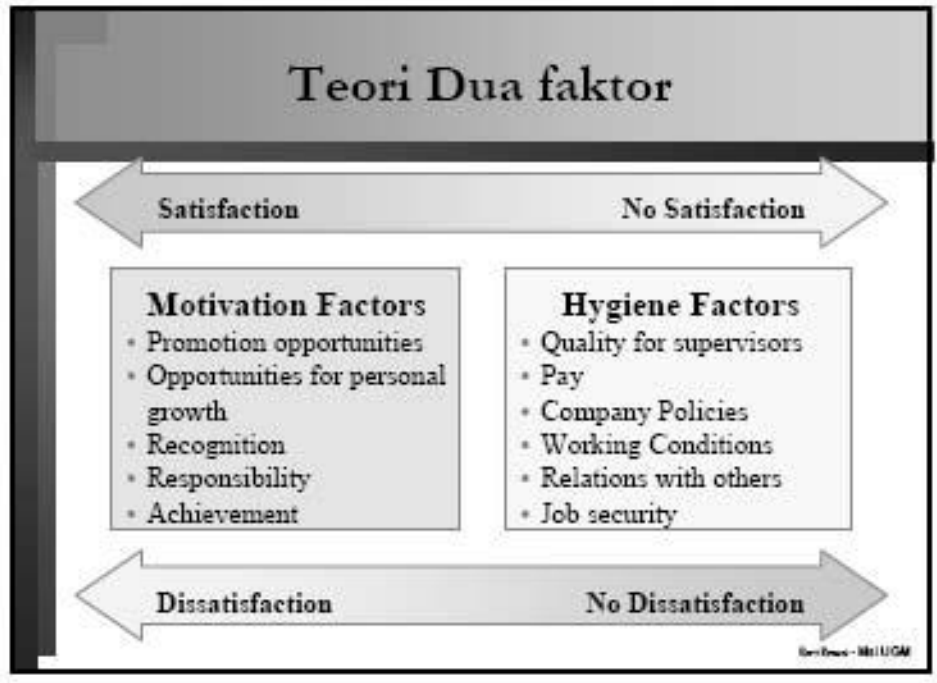

\section{Faktor-Faktor yang Mempengaruhi Kepuasan Kerja}

Dalam hal kepuasan kerja, Gilmer (1966) menyebutkan faktorfaktor yang mempengaruhi kepuasan kerja adalah kesempatan untuk maju, keamanan kerja, gaji, perusahaan dan manajemen, faktor intrinsik dan pekerjaan, kondisi kerja, aspek sosial dalam pekerjaan, komunikasi, dan fasilitas. ${ }^{5}$

Sementara itu, menurut Heidjrachman dan Husnan mengemukakan beberapa faktor mengenai kebutuhan dan keinginan pegawai, yakni: gaji yang baik, pekerjaan yang aman, rekan sekerja yang kompak, penghargaan terhadap pekerjaan, pekerjaan yang berarti, kesempatan untuk maju, pimpinan yang adil dan bijaksana, pengarahan dan perintah yang wajar, dan organisasi atau tempat kerja yang dihargai oleh masyarakat. ${ }^{6}$

Kepuasan kerja merupakan persoalan umum pada setiap unit kerja, baik itu berhubungan motivasi, kesetiaan ataupun ketenangan bekerja, dan disiplin kerja. Harold E. Burt mengemukakan pendapatnya tentang faktorfaktor yang dapat menimbulkan kepuasan kerja adalah: Pertama, faktor hubungan antar pekerja, antara lain:

1. Hubungan antara Pimpinan dengan karyawan,

${ }^{5}$ Ibid.

${ }^{6}$ Heidjrachman dan Suad Husnan (2002), Manajemen Personalia, Yogjakarta: BPFE, hlm. 194 
2. Faktor fisik dan kondisi kerja,

3. Hubungan sosial di antara karyawan,

4. Sugesti dari teman sekerja,

5. Emosi dan situasi kerja.

Kedua, faktor indivual, yaitu yang berhubungan dengan sikap orang terhadap pekerjaannya, umur orang sewaktu bekerja, dan jenis kelamin. Dan Ketiga, faktor luar (extern), yang berhubungan dengan keadaan keluarga karyawan, rekreasi, pendidikan (training, up grading, dan sebagainya). ${ }^{7}$

Menurut Loeke, kepuasan atau ketidakpuasan karyawan tergantung pada perbedaan antara apa yang diharapkan. Sebaliknya, apabila yang didapat karyawan lebih rendah daripada yang diharapkan akan menyebabkan karyawan tidak puas. Faktor-faktor yang mempengaruhi kepuasan atau ketidakpuasan kerja yaitu: jenis pekerjaan, rekan kerja, tunjangan, perlakuan yang adil, keamanan kerja, peluang menyumbang gagasan, gaji/upah, pengakuan kinerja, dan kesempatan berkembang. ${ }^{8}$

Merujuk pada berbagai pendapat tersebut dapat disimpulkan mengenai faktor-faktor yang mempengaruhi kepuasan kerja karyawan dalam rangka peningkatan kinerjanya adalah: (a) faktor psikologis, merupakan faktor yang berhubungan dengan kejiwaan karyawan yang meliputi minat, ketenteraman dalam kerja, sikap terhadap kerja, bakat, dan keterampilan; (b) faktor sosial, merupakan faktor yang berhubungan dengan interaksi sosial baik sesama karyawan, dengan atasannya, maupun karyawan yang berbeda jenis pekerjaannya; (c) faktor fisik, merupakan faktor yang berhubungan dengan kondisi fisik lingkungan kerja dan kondisi fisik karyawan, meliputi. Jenis pekerjaan, pengaturan waktu kerja dan waktu istirahat, perlengkapan kerja, keadaan ruangan, suhu penerangan, pertukaran udara, kondisi kesehatan karyawan, umur, dan sebagainya; (d) faktor finansial, merupakan faktor yang berhubungan dengan jaminan serta kesejahteraan karyawan yang meliputi sistem dan besarnya gaji, jaminan sosial, macam-macam tunjangan, fasilitas yang diberikan, promosi, dan sebagainya.

7Porwanto dan Wahyudin, Pengaruh Faktor-Faktor Kepuasan Kerja Terhadap Kinerja Karyawan Pusat Pendidikan Komputer Akuntansi IMKA D1 Surakarta, Surakarta: PPS UMS, 2006.

${ }^{8}$ Sule, E. (2002), Keterkaitan antara Kepuasan Kerja Karyawan dan Kepuasan Pelanggan dengan Kinerja Perusahaan Yogyakarta: STIE YKPN, hlm. 211 


\section{Kepuasan Kerja dalam Pendidikan Islam; Guru dan Permasalahannya}

Kualitas mutu guru di Indonesia memang jauh berbeda dengan guru-guru di negara tetangga. Banyak faktor yang mempengaruhi kualitas guru bangsa ini, diantaranya adalah profesionalisme dan kesejahteraan.

Profesionalisme dan kesejahteraan guru, meskipun sesuatu yang berbeda tetapi sebenarnya merupakan satu kesatuan. Walaupun profesionalisme bukanlah fungsi dari kesejahteraan, atau sebaliknya guru yang profesional belum tentu sejahtera, secara ideal kedua sifat itu, profesional dan sejahtera seharusnya melekat pada setiap guru. Artinya, guru yang profesional akan berdampak pada kesejahteraan, atau sebaliknya, karena kesejahteraannya tercukupi, guru akan lebih profesional. Dan ini sedikit banyaknya akan berpengaruh pada kepuasan kerja mereka. ${ }^{9}$

Apabila kita melihat ketiga teori kepuasan kerja di atas maka kita akan bisa melihat apakah kepuasan kerja sudah dimiliki oleh guru-guru di Indonesia, atau belum.

Berdasarkan teori pertentangan yang mengukur kepuasan kerja berdasarkan perbandingan antara apa yang diharapkan dengan apa yang didapatkan. Menjadi guru (PNS) dengan hidup yang terjamin berkat gaji bulanan dan tanggungan pensiun, mungkin merupakan harapan sebagian masyarakat Indonesia. Tapi, dengan keadaan ekonomi yang tidak semakin baik, bahkan cenderung makin berat memaksa para pendidik bangsa untuk mencari pendapatan lain disamping pekerjaan utama mereka. Tukang becak, tukang ojek, pemulung, buka usaha, bertani, dan lain sebagainya menjadi pilihan untuk menambah pendapatan mereka.

Masalah gaji bukan satu-satunya faktor penentu kepuasan kerja para guru. Namun perilaku seperti ini merupakan sebuah indikasi kurangnya tingkat kepuasan yang mereka miliki (unsatisfied worker). Inilah yang disebut dengan penyimpangan perilaku kerja (turnover) yang saat ini dilakukan oleh sebagian guru.

Penyimpangan perilaku kerja ini kemudian akan berpengaruh pada profesionalitas guru. Mangkir kerja/membolos (absenteeism) bisa menjadi hal yang lumrah dilakukan. Seperti hanya dengan menitipkan catatan kepada salah satu siswa untuk disalin bersama di kelas kemudian sang guru melakukan pekerjaan lain, dan lain sebagainya merupakan dampak jangka

${ }^{9}$ Sutrisno Wibowo, Debat Profesionalisme Guru Era Otonomi Daerah, Kerja

Sama UNY-KR; Profesionalisme Dan Kesejahteraan Guru, data on line (http://www.kebumen.go.id/) diakses tanggal: 07 Oktober 2006. 
pendek yang bisa dirasakan.

Kemudian berdasarkan elemen-elemen kepuasan yang dicakup dalam teori yang kedua, teori keadilan, maka tentang masalah input, apa yang dirasakan seorang guru sebagai masukan terhadap pekerjaannya, penulis akan mencoba menyoroti masalah penempatan guru yang tidak merata, atau sang guru itu sendiri yang merasa bahwa penempatannya tidak adil karena ditugaskan di daerah pelosok, misalnya. Hal ini sedikit banyak juga akan mempengaruhi kepuasan kerja. Karena dengan membandingkan dirinya dengan rekan-rekan sejawat yang ditugaskan di daerah kota yang mempunyai lingkungan kerja dan kesempatan berkembang yang lebih baik, atau dekat dengan tempat domisili, maka hal ini juga akan mempengaruhi kepuasan kerja guru.

Keadilan input yang dirasakan guru dalam menjalankan tugasnya ini juga bisa kita kaitkan dengan masalah sarana yang dimiliki masingmasing sekolah, seperti peralatan praktek laboratorium, buku, dan fasilitas lainnya. Kita semua menyadari bahwa fasilitas yang dimiliki sekolahsekolah di negeri yang kita cinta ini masih belum bisa dikatakan merata. Dengan alasan lokasi dan proses pengiriman yang tidak mendukung, maka banyak sekolah di pedesaan atau tempat terpencil lainnya yang belum bisa memiliki fasilitas yang dapat mendukung proses belajar mengajar. Hal ini tentu akan berpengaruh pada kepuasan guru dalam melakukan proses belajar mengajar, karena ketika guru membutuhkan alat untuk digunakan dalam praktek kelas, ternyata alat yang dibutuhkan tidak dimiliki oleh sekolah, sehingga proses belajar pun menjadi seadanya.

Begitu juga dengan kesempatan untuk mengembangkan profesionalitas diri. Dengan fasilitas seadanya, mereka akan sangat kesulitan untuk melakukan hal-hal yang dapat mengembangkan kemampuan mereka, atau untuk melakukan tugas-tugas yang harus dipenuhi untuk kenaikan pangkat, menyusun karya ilmiah misalnya. Dengan persedian referensi yang terbatas, dan tidak adanya jaringan internet yang bisa dicapai, tentu ini adalah kendala yang akan dihadapi oleh guru-guru di daerah.

Dengan membandingkan keadaan mereka dan keadaan rekanrekan sejawat yang "lebih beruntung", maka tingkat kepuasan kerja para guru di daerah akan sangat mudah menurun hingga mempengaruhi kinerja mereka secara keseluruhan.

Kemudian elemen out comes yang dirasakan oleh para guru. Ketika mereka sudah berusaha keras dalam melaksanakan pekerjaannya, maka ada beberapa hal yang dapat mempengaruhi kepuasan kerja yang 
mereka rasakan. Diantaranya, anak didik yang berprestasi dalam pelajaran, menang dalam lombalomba ilmu pengetahuan, atau lulus dalam ujian akhir nasional (UAN), dan lain sebagainya.

Sedangkan berdasar elemen comparison persona, maka untuk mengukur kepuasan kerja yang dimilikinya, seorang guru akan mencoba membandingkan antara apa yang dia dapatkan/lakukan dengan apa yang dia hasilkan. Kedua faktor ini harus seimbang untuk memunculkan kepuasan atas pekerjaan yang telah dia lakukan.

Terakhir, berdasarkan teori ketiga, two factor theory, dikemukakan oleh Herzberg (1966), yang memisahkan antara faktor yang menjadi sumber kepuasan dan ketidakpuasan kerja, maka faktor-faktor satisfier yang berupa penghargaan (achievement) dan pengakuan (recognition) yang diberikan oleh masyarakat kepada guru. Karena bagi kebanyakan masyarakat Indonesia, terutama yang di pedesaan, guru masih merupakan figur yang sangat dihormati berkat jasa-jasanya dalam mendidik masyarakat. Selain dari masyarakat, apabila kedua hal itu didapatkan dari atasan juga dapat menumbuhkan kepuasan kerja di hati para guru.

Lalu, masalah menjadi guru (work it self), tanggung jawab (responsibility), dan kemajuan yang dicapai (advancement) akan lebih dipengaruhi oleh sikap (attitude) yang dimiliki guru.

Sedangkan faktor dissatisfiers, apabila kita menelaahnya satu persatu, maka kita akan melihat bahwa hampir semua faktor ini dapat berpengaruh besar pada profesi guru di Indonesia. Masalah policy and administration (kebijakan dan administrasi), supervision technical (teknik supervisi), salary (gaji), interpersonal relations (hubungan antar pribadi), working condition (kondisi kerja), job security (keamanan kerja) dan status.

\section{E. Menumbuhkan Kepuasan Kerja Guru di Indonesia}

Setelah pemaparan realitas di atas, mungkin kita bisa mencoba untuk mencari bagaimana cara menumbuhkan kepuasan kerja para guru agar mereka mampu meningkatkan kinerja mereka dalam mencerdaskan anak bangsa.

Dengan berbagai teori kepuasan di atas, mungkin ada beberapa hal yang patut dicermati oleh siapa saja yang bertanggung jawab terhadap proses pendidikan di bangsa ini, baik dari yang paling tinggi hingga para guru sebagai ujung tombak sistem pendidikan nasional. Diantara hal yang perlu diperhatikan adalah:

1. Pemerataan pemenuhan standar pendidikan, sehingga tidak ada kesenjangan mutu pendidikan. Dengan fasilitas standar yang 
terpenuhi, maka ini akan bersinggungan langsung dengan kepuasan para guru dalam melaksanakan tugas-tugas mereka.

2. Gaji, walaupun bukan faktor satu-satunya dalam memicu kepuasan guru, ternyata ini merupakan faktor signifikan. Sehingga, pelaksanaan sertifikasi guru yang saat ini sedang dilangsungkan dan berimplikasi pada tunjangan/gaji yang didapatkan oleh guru harus dilaksanakan secara seksama dan terkontrol.

3. Kepala sekolah harus memahami betul dan mempunyai kompetensi kepemimpinan pendidikan sehingga dia mampu mendeteksi tingkat kepuasan dan kinerja guru yang berada dibawah kepemimpinannya. Agar setiap gejala penyimpangan dan absenteeism dapat dideteksi secara dini untuk dilakukan pembenahan dan koreksi terhadap menurunnya kepuasan guru. Pembenahan ini tidak saja yang bersifat fisik, namun juga mental dengan selalu memberi motivasi atau dorongan positif.

4. Para guru, dengan menumbuhkan kesadaran atas tugas yang diemban dan meningkatkan profesionalitas diri, ini akan mampu meningkatkan kepuasan kerja pribadi. Karena dengan profesionalitas kerja, rasa bangga dan puas akan dapat dicapai ketika hasil dari pendidikan -yang dapat diukur lewat kompetensi anak didik yang mereka bina- dapat dilihat kemajuan dan keberhasilan dari jerih payah yang mereka lakukan dengan sebagai profesional.

\section{F. Penutup}

Setelah pembahasan singkat di atas, kita dapat menarik suatu kesimpulan bahwa kepuasan kerja pada personalia pendidikan, terutama guru, memiliki keterikatan dengan banyak hal, seperti Faktor psikologis, yang berhubungan dengan kejiwaan dan sikap guru, meliputi minat, ketenteraman dalam kerja, sikap terhadap kerja, bakat, dan keterampilan; Faktor sosial, merupakan faktor yang berhubungan dengan interaksi sosial dengan atasan, sesama sejawat, anak didik, maupun masyarakat. Faktor fisik, merupakan faktor yang berhubungan dengan kondisi fisik sekolah/madrasah dan kondisi fisik guru, meliputi kebijakan-kebijakan, jenis pekerjaan, pengaturan waktu kerja dan waktu istirahat, fasilitas sekolah, perlengkapan sarana mengajar, keadaan kelas dan kantor guru, kondisi kesehatan, umur, dan sebagainya. Faktor finansial, merupakan faktor yang berhubungan dengan jaminan serta kesejahteraan guru yang meliputi gaji, jaminan sosial, macam-macam tunjangan, fasilitas yang 
diberikan, promosi, dan sebagainya. Semua faktor ini tentu tidak bisa dirubah hanya oleh pihak guru saja, namun mereka juga membutuhkan bantuan dari pihak-pihak luar, baik pemerintah maupun masyarakat. Supaya kepuasan kerja para guru meningkat dan berimplikasi pada profesionalitas dan motivasi kerja.

\section{DAFTAR PUSTAKA}

Armstrong, M. (1994), Manajemen Sumber Daya Manusia, Jakarta: Media Kompetindo.

As'ad, M (2003), Psikologi Industri; Seri Sumber Daya Manusia, Yogyakarta: Liberty.

Hamid, E.S (2003), Membangun Profesional Muhammadiyah, Yogyakarta: LPTP Muhammadiyah dan UAD PRESS.

Handoko, T. Hani (2001), Manajemen Personalia dan Sumber Daya Manusia, Yogyakarta: BPFE .

Heidjrachman dan Suad Husnan (2002), Manajemen Personalia, Yogyakarta: BPFE.

Martoyo (2000), Manajemen Sumber Daya Manusia, Yogyakarta: BPFE.

Sule, E. (2002), Keterkaitan antara Kepuasan Kerja Karyawan dan Kepuasan Pelanggan dengan Kinerja Perusahaan Yogyakarta: STIE YKPN.

Sutrisno Wibowo, Debat Profesionalisme Guru Era Otonomi Daerah, Kerja

Sama UNY-KR; Profesionalisme Dan Kesejahteraan Guru, data on line (http://www.kebumen.go.id/) diakses tanggal: 07 Oktober 2006. 